\title{
KEPUTUSAN DIVERSIFIKASI TANAMAN UNTUK MENGEJAR PEMBANGUNAN PERTANIAN DI INDONESIA
}

\begin{tabular}{|c|}
\hline Kartika Eka Pratiwi \\
Universitas Indonesia \\
kartikaekapratiwi7@ gmail.com \\
\hline
\end{tabular}

\section{Diterima: Desember 2020; Disetujui: Juli 2021}

\begin{abstract}
The narrative of agricultural development related to diversification and specialization in developing countries is still being debated. This study analyzes the determinants of diversification decisions according to the characteristics of food crop agriculture households in Indonesia and determines the characteristics of households that need intervention in agricultural diversification. By using logistic regression analysis, the results are obtained those farmers decide to diversify when conditions are limited in terms of income, land ownership not own property and poor crop conditions due to pest attacks. When conditions are more stable, for example, when they get older, the value of production has increased and they already have their own agricultural land, they tend to choose to plant one type of plant. Diversification is one solution to keep the supply chain for basic needs stable so that food security can be fulfilled.
\end{abstract}

Keywords: diversification, logistics regression, SOUT2017.

Abstraksi. Narasi pembangunan pertanian terkait diversifikasi maupun spesialisasi di negara berkembang masih menjadi perdebatan. Penelitian ini menganalisis determinan keputusan diversifikasi menurut karakteristik rumah tangga pertanian tanaman pangan di Indonesia dan menentukan karakteristik rumah tangga yang perlu mendapat intervensi terkait diversifikasi pertanian. Dengan menggunakan analisis regresi logistik, diperoleh hasil bahwa petani memutuskan diversifikasi saat kondisi terbatas dari sisi pendapatan, kepemilikan lahan bukan milik sendiri serta kondisi tanaman yang buruk akibat serangan hama. Ketika kondisi lebih stabil misal usia semakin matang, nilai produksi yang sudah meningkat dan sudah memiliki lahan pertanian milik sendiri, mereka cenderung memilih menanam satu jenis tanaman. Diversifikasi menjadi salah satu solusi untuk menjaga supply chain akan kebutuhan pokok tetap stabil sehingga ketahanan pangan pun akan terpenuhi.

Kata kunci: diversifikasi, regresi logistik, SOUT2017.

\section{PENDAHULUAN}

Pengentasan kemiskinan telah menjadi hal utama dalam perdebatan internasional sejak tahun 1970-an. Pada tahun 2015, negara-negara anggota Perserikatan BangsaBangsa mengadopsi Sustainable Development Goals (SDGs) dengan target pertamanya "Mengakhiri Kemiskinan dalam Bentuk Apapun dan Dimanapun" (United Nations, 2015). (Alkire, Kanagaratnam, \& Suppa, 2015) menyatakan bahwa 85 persen dari semua orang miskin di 105 negara hidup di daerah pedesaan. International Fund For

\section{Agriculture Development} menyatakan bahwa kesejahteraan pertanian skala kecil ( $<2$ hektar dan rendah basis aset) merupakan rute keluar dari kemiskinan bagi banyak orang yang tinggal di area pedesaan. Maka dari itu pertumbuhan sektor pertanian lebih banyak mengurangi kemiskinan daripada pertumbuhan di sektor lain. Menurut Food and Agriculture Organization (FAO), petani skala kecil menghasilkan banyak pasokan pangan bagi negara berkembang akan tetapi umumnya mereka hidup jauh lebih miskin daripada 
populasi lainnya dan lebih rawan pangan daripada orang miskin di perkotaan (FAO, 2011). Bank Dunia (2008) mengatakan pembangunan sektor pertanian sangat menentukan untuk keluar dari perangkap kemiskinan di banyak negara berkembang.

Pada narasi konvensional, pembangunan pertanian diwujudkan melalui spesialisasi pertanian berbasis pasar (Timmer, 1997). Pendapat ini dipakai selama beberapa dekade di bawah program Revolusi Hijau. Pada praktiknya di Indonesia, Revolusi Hijau mengalami kegagalan akibat ketergantungan petani pada bahan kimia sehingga merusak keseimbangan ekosistem tanah. Selanjutnya, narasi alternatif yang digaungkan adalah diversifikasi pertanian berbasis pasar. Diversifikasi tanaman dianggap sebagai salah satu dari cara yang paling layak secara ekologis, hemat biaya, dan lebih mudah mengurangi efek ketidakpastian, terutama di kalangan skala kecil petani. Diversifikasi tanaman dapat didefinisikan sebagai penambahan lebih banyak tanaman ke sistem penanaman yang ada, penggantian komoditas bernilai rendah dengan komoditas bernilai tinggi (biasanya buah dan sayuran untuk pasar ekspor), integrasi tanaman dan ternak (biasanya didefinisikan sebagai pertanian campuran), integrasi tanaman dan pohon (biasanya didefinisikan sebagai agroforestri) atau memproduksi tanaman komersial (contohnya kopi dan mete).

Kedua narasi pembangunan pertanian tersebut didasarkan pada partisipasi kuat petani di pasar (Emran \& Shilpi, 2012). Akan tetapi, walaupun pasar untuk input dan output tersedia di sebagian besar daerah pedesaan di negara berkembang dan sebagian besar rumah tangga pedesaan berpartisipasi di dalamnya baik sebagai konsumen maupun produsen, pasar umumnya cenderung berfungsi buruk
(Dillon \& Barrett, 2017). Oleh karena itu, harga komoditas pertanian menjadi sinyal nilai yang menyesatkan, dan profitabilitas dapat menjadi sumber informasi yang terdistorsi untuk memahami keputusan pertanian petani kecil dan hasil kesejahteraan yang dihasilkannya. Pada sistem pertanian yang semakin kompleks, kegagalan untuk memperhitungkan faktor ekonomi, seperti konsumsi sendiri, nilainilai budaya dan preferensi, tidak memadai. Insentif yang rumit ini menopang strategi banyak petani kecil di negara-negara berkembang untuk terus menanam banyak spesies tanaman dalam sistem pertanian terpadu atau dapat disebut sebagai upaya mempertahankan keanekaragaman tanaman.

Di sisi lain, intervensi kebijakan terkait dengan pengembangan pertanian jarang mempertimbangkan keanekaragaman tanaman yang dilakukan oleh petani kecil sebagai titik masuk untuk mendorong inovasi pertanian. Ini adalah area yang perlu mendapat perhatian lebih lanjut karena meningkatnya pengakuan akan beragam manfaat dari keanekaragaman tanaman bagi kesejahteraan petani kecil. Intervensi yang berhasil mampu menangani kebutuhan dan prioritas penerima manfaat sasaran mereka. Oleh karena itu, jika keanekaragaman tanaman merupakan komponen penting dan berharga dari sistem pertanian dan mata pencaharian petani kecil, memasukkan keanekaragaman tanaman dalam pengembangan intervensi menjadi sangat penting untuk meningkatkan kesejahteraan mereka (Bellon, Gotor, \& Caracciolo, Conserving landraces and improving livelihoods: how to assess the success of on farm, 2015).

Pada masa pandemik seperti saat ini, pertanian tanaman pangan menjadi peran utama dalam ketersediaan bahan pokok konsumsi masyarakat. Diversifikasi menjadi 
salah satu solusi untuk menjaga supply chain akan kebutuhan pokok tetap stabil sehingga ketahanan pangan masyarakat pun akan terpenuhi. Pada penerapannya di Indonesia, praktik diversifikasi telah mendominasi dibandingkan spesialisasi. Pada tahun 2018, sebesar 63 persen petani yang mengelola lebih dari satu subsektor pertanian, selebihnya melakukan spesialisasi pada satu subsektor (BPS, 2018).

- Spesialisasi Pertanian Diversifikasi Pertanian

Gambar 1. Persentase Petani yang

Melakukan Spesialisasi Pertanian pada Satu

Subsektor dan Lebih dari Satu Subsektor

Sumber: SOUT, rawdata, diolah 2017

Namun demikian, Indonesia masih didominasi petani skala kecil bahkan ratarata luas lahan yang dikuasai tidak sampai 1 hektar. Pada 2018 sebanyak 89,09 persen petani Indonesia menguasai lahan pertanian kurang dari 2 hektar. Adapun rata-rata luas lahan pertanian yang dikuasai pada 2018 hanya 0,779 hektar. Angka ini tentu mempengaruhi produktivitas serta kesejahteraan petani Indonesia yang rendah.

Tidak dapat dipungkiri, kebutuhan hidup yang besar menuntut petani untuk melakukan optimisasi dengan berbagai cara, salah satunya diversifikasi terhadap tanamannya. Kemudian, sebagian besar petani memilih untuk mengonsumsi sendiri hasil produksinya atau sering disebut petani subsisten. Dari latar belakang ini, maka perlu dilakukan penelitian untuk menganalisis bagaimana karakteristik rumah tangga pertanian tanaman pangan di Indonesia untuk memutuskan melakukan diversifikasi terhadap tanamannya serta bagaimana dampak diversifikasi yang dilakukannya dengan nilai produksi yang dijual serta yang dikonsumsi sendiri. Kedua variabel ini (nilai produksi yang dikonsumsi dan nilai produksi yang dijual) secara langsung berdampak pada kesejahteraan rumah tangga. Poin pertama secara langsung mempengaruhi konsumsi makanan, keragaman makanan, dan keamanan pangan. Poin kedua mempengaruhi kemampuan untuk membeli barang dan jasa di pasar, dan dengan demikian memiliki efek tidak langsung pada makanan yang dikonsumsi, keanekaragaman makanan dan ketahanan pangan, serta dalam dimensi kesejahteraan lainnya seperti kesehatan, perumahan, dan pendidikan.

Diversifikasi tanaman, bagaimanapun, dapat berhubungan secara berbeda dalam hal besarnya dan arah untuk konsumsi sendiri dan pendapatan tunai (Bellon, Kotu, Azzarri, \& Caracciolo, 2020) melalui strategi pembangunan pertanian yang berbeda. Apabila arah hubungan antara keanekaragaman tanaman dan masingmasing variabel interest sama, menunjukkan bahwa strategi kebijakan yang sama antara diversifikasi maupun spesialisasi untuk kedua hasil. Sementara, jika hubungannya berbeda akan menunjukkan bahwa strategi ini bertentangan. Dengan memeriksa keberadaan dan arah hubungan ini, diharapkan dapat menilai apakah petani tanaman pangan di Indonesia dapat memperoleh manfaat lebih dari intervensi yang lebih fokus pada diversifikasi pertanian atau strategi spesialisasi.

Berbeda dengan penelitian terdahulu (Bellon, Kotu, Azzarri, \& Caracciolo, 2020), penelitian ini menambahkan variabel terkait 
institusi serta kepemilikan lahan. Variabel bebas yang digunakan pada penelitian sebelumnya hanya mencakup karakteristik demografi, akses informasi, luas tanam, serta ketersediaan aset. Akses dan ketersediaan lahan adalah pendorong utama diversifikasi. Petani yang kekurangan lahan yang cukup sering memprioritaskan produksi makanan pokok, dengan mengorbankan tanaman lainnya. Salah satu elemen sentral yang seharusnya menjadi salah satu strategi diversifikasi tanaman yang lebih luas adalah dengan mengatasi fragmentasi tanah (FAO, 2018). Selain ketersediaan akses informasi, peran kelembagaan dalam memberikan kebijakan pertanian mempengaruhi keputusan petani menjalankan praktik diversifikasi tanaman. Sebagai contoh, ketersediaan bantuan pupuk maupun benih bagi berbagai jenis komoditas akan menarik petani untuk menanam tanaman lebih beragam.

Khusus di Indonesia, penelitian empiris mengenai diversifikasi dengan unit analisis rumah tangga masih sangat terbatas. Pada umumnya, penelitian terdahulu pada teknik pertanian dalam diversifikasi. Peneliti hanya menemukan satu penelitian serupa, yakni yang dilakukan oleh (Mu'min, Hastuti, \& Angriani, 2014). Penelitian dilakukan dengan sampel 240 petani padi yang berasal dari salah satu desa di Provinsi Lampung. Dibandingkan penelitian tersebut, penelitian ini memberi kontribusi berupa (1) perluasan cakupan sampel yang melibatkan rumah tangga pertanian tanaman pangan dari seluruh provinsi di Indonesia, (2) penambahan jumlah sampel menjadi 356.000 rumah tangga, (3) penggunaan data terkini yaitu tahun 2017, dan (4) penambahan aspek peranan kelembagaan dan akses informasi seperti telah dijelaskan sebelumnya. Perluasan cakupan sampel dan praktik diversifikasi pertanian, penambahan jumlah sampel, serta penggunaan data terkini diharapkan dapat memberikan hasil yang menggambarkan kondisi terkini dari perilaku petani tanaman pangan di seluruh Indonesia, bukan hanya perilaku petani salah satu komoditas tanaman pangan pada wilayah tertentu saja. Sedangkan penambahan aspek peranan institusi dan akses informasi, dilakukan untuk meminimalkan bias yang mungkin terjadi sehingga diperoleh estimator yang semakin mendekati nilai sebenarnya.

Berdasarkan permasalahan tersebut, maka dirumuskanlah pertanyaan penelitian ini adalah (1) bagaimana keputusan diversifikasi pertanian tanaman pangan menurut karakteristik rumah tangga tani di Indonesia dan (2) bagaimana karakteristik rumah tangga tani yang perlu mendapatkan intervensi terkait diversifikasi terhadap tanamannya? Berdasarkan perumusan masalah yang ada, maka penelitian ini bertujuan untuk (1) menganalisis determinan diversifikasi menurut karakteristik rumah tangga di Indonesia dengan analisis deskriptif dan regresi logistik; dan (2) menentukan karakteristik rumah tangga yang perlu mendapat intervensi terkait diversifikasi pertanian.

Berdasarkan tujuan penelitian, diharapkan hasil dari penelitian ini dapat memberikan manfaat, yaitu (1) diperolehnya informasi mengenai determinan diversifikasi menurut karakteristik rumah tangga di Indonesia; serta (2) menentukan strategi intervensi terkait diversifikasi pertanian.

\section{Tinjauan Literatur}

Keputusan rumah tangga untuk melakukan diversifikasi dianggap sebagai keputusan ekonomi utama yang memiliki pengaruh kuat pada mata pencahariannya (Pope \& Prescott, 1980). Ketika petani 
membuat pilihan tentang produksi pertanian, ia dianggap memutuskan strategi tanam yang meningkatkan ketahanan dan memberikan manfaat ekonomi, dengan mempertimbangkan berbagai bentuk kombinasi tanaman pada skala yang berbeda (Lin 2011). Oleh karena itu, model rumah tangga pertanian dapat memberikan kerangka kerja analitis untuk faktor-faktor yang mendorong diversifikasi tanaman, di mana rumah tangga merupakan unit terkecil dalam pengelolaan pertanian yang membuat pilihan pada produksi pertanian dan mengambil tindakan.

Oleh karena sebagian besar $(63,64$ persen) rumah tangga pertanian di Indonesia bergantung sepenuhnya pada produksi mereka sendiri untuk kebutuhan makanan serta untuk menghasilkan pendapatan, maka perilaku mereka dapat dipahami dengan menggunakan teori konsumen dan produsen. (Singh, Squire, \& Strauss, 1986) mengembangkan model rumah tangga pertanian untuk menjelaskan dasar-dasar pengambilan keputusan dalam rumah tangga petani kecil. Model ini dibangun berdasarkan teori konsumen dan teori produsen (Singh et al. 1986; Becker 1976). (Mattila \& Wiro, 1999) menjelaskan bahwa sebuah rumah tangga (dalam konteks perusahaan bisnis) menghadapi batas kemungkinan produksi dalam periode waktu tertentu dan dengan sumber daya yang terbatas untuk penggunaan alternatif. Rumah tangga kemudian akan membuat keputusan yang sebagian besar didasarkan pada pemaksimalan laba, meskipun untuk petani kecil mungkin ada faktor pendorong tambahan. Becker (1976) menunjukkan bahwa keputusan untuk mengalokasikan sumber daya di mana produksi rumah tangga akan optimal sering dibuat tanpa mempertimbangkan pilihan waktu luang dan konsumsi.
Namun, keputusan tentang alokasi tenaga kerja keluarga dan konsumsi komoditas didasarkan pada tingkat pendapatan maksimum yang diperoleh dari produksi yang memaksimalkan keuntungan. Dengan asumsi bahwa rumah tangga membuat keputusan untuk melakukan diversifikasi (A $=1)$ atau tidak $(\mathrm{A}=0)$, fungsi utilitas dapat dinyatakan sebagai $\mathrm{U}=\mathrm{U}\left(H_{j i} D_{j i}\right)$ di mana $H_{j i}$ mewakili karakter rumah tangga sementara $D_{j i}$ mewakili atribut khusus diversifikasi (Singh et al. 1986). Fungsi utilitas tidak dapat diobservasi dan memberi peringkat pada rumah tangga " $\mathrm{i}$ " dan proses diversifikasi " $\mathrm{j}$ " sebagai $\mathrm{i}$ atau $\mathrm{j}=1$ atau $0 \mathrm{di}$ mana 1 adalah diversifikasi lengkap dan 0 bukan diversifikasi. Dalam hal ini maksimisasi utilitas menjadi fungsi rumah tangga yang dapat diamati dan karakteristik khusus diversifikasi dan kerangka kerja analitik yang sesuai adalah model rekursif dengan komponen yang memaksimalkan keuntungan dan utilitas (Singh et al. 1986). Mengingat bahwa utilitas bersifat acak, rumah tangga akan memilih alternatif $\mathrm{j}=1$ jika $U_{1 i}>U_{0 i}$ atau jika variabel acak yang tidak dapat diamati (laten) $\mathrm{y}^{*}=U_{1 i}-U_{0 i}>$ 0 . Probabilitas bahwa $Y_{i}=1$ (yaitu, bahwa petani melakukan diversifikasi tanaman) adalah fungsi dari beberapa variabel penjelas.

\section{METODE PENELITIAN}

Unit analisis dalam penelitian ini adalah data rumah tangga pertanian. Rumah tangga usaha pertanian yang dicakup dalam penelitian ini adalah rumah tangga usaha pertanian tanaman pangan. Cakupan komoditas tanaman pangan sendiri meliputi padi sawah, padi ladang, jagung hibrida, jagung komposit, kedelai, kacang hijau, kacang tanah, ubi kayu, dan ubi jalar. Komoditas tanaman pangan dipilih karena beberapa alasan. Pertama, subsektor 
tanaman pangan merupakan subsektor yang mendominasi kegiatan pertanian di Indonesia. Pada tahun 2018 sebanyak 73,28 persen rumah tangga usaha pertanian di Indonesia mengusahakan komoditas padi dan palawija (BPS RI, 2018). Karena jumlahnya yang cukup banyak, maka pengaruh dari keputusan petani di subsektor ini terkait penerapan praktik pembangunan pertanian akan besar. Kedua, berdasarkan acuan nasional (BKP, 2015), idealnya sebesar 61 persen energi yang dibutuhkan oleh tubuh berasal dari kelompok tanaman pangan, yakni padi-padian, umbi-umbian, serta kacang-kacangan. Oleh karena itu, pembangunan pertanian pada komoditas tanaman pangan perlu menjadi prioritas (Pratiwi, 2020).

Penelitian ini menggunakan data sekunder berupa hasil Survei Struktur Ongkos Usaha Tanaman Pangan (Padi dan Palawija) SOUT Tahun 2017 bersumber Badan Pusat Statistik RI. Selain alasan kemutakhiran data rumah tangga pertanian tanaman pangan, data tersebut dipilih karena kelengkapan informasi di dalamnya. Hasil dari SOUT 2017 mencakup profil rumah tangga usaha tanaman padi, struktur ongkos usaha tanaman padi, dan sosial ekonomi rumah tangga usaha tanaman padi. SOUT2017 dilakukan di 34 provinsi di Indonesia. SOUT Tanaman Pangan Tahun 2017 ini merupakan survei struktur ongkos terhadap rumah tangga pertanian yang pertama di Indonesia.

Pengambilan sampel dilakukan secara dua tahap (two stages sampling method). Pada tahap pertama, dari kerangka sampel blok sensus, dipilih sejumlah blok sensus secara probability proportional to size (PPS) dengan size jumlah rumah tangga usaha tanaman padi hasil ST2013-L. Tahap kedua, dari kerangka sampel rumah tangga dipilih sejumlah rumah tangga secara sistematik (systematic random sampling). Sampel dalam penelitian ini berjumlah 356.000 rumah tangga pertanian tanaman pangan atau 2,5 persen dari jumlah rumah tangga tani hasil Sensus Pertanian 2013.

Rumah tangga padi yang dicakup pada kerangka sampel adalah rumah tangga yang mengusahakan padi selama setahun yang lalu dengan luas tanam lebih dari batas minimum usaha (BMU) yaitu untuk tanaman padi sawah hibrida dan inbrida adalah 550 $\mathrm{m}^{2}$; tanaman padi ladang $1000 \mathrm{~m}^{2}$; tanaman jagung adalah yang memiliki luas panen seluas $1.500 \mathrm{~m}^{2}$ selama setahun yang lalu, kedelai $2.000 \mathrm{~m}^{2}$, kacang tanah $1.500 \mathrm{~m}^{2}$, kacang hijau $1.500 \mathrm{~m}^{2}$, ubi kayu $700 \mathrm{~m}^{2}$, dan ubi jalar $700 \mathrm{~m}^{2}$.

Sebelum dikontrol dengan variabel lain, dilakukan analisis deskriptif masing-masing variabel yang diduga mempengaruhi diversifikasi pertanian tanaman pangan di Indonesia. Secara inferensia, akan dianalisis menggunakan metode analisis regresi logit.

Keputusan diversifikasi dapat diartikan sebagai model pilihan biner. Perbedaan utilitas laten antara diversifikasi dan nondiversifikasi $\mathrm{y}^{*}$, diasumsikan ditentukan oleh fungsi linear dari karakteristik yang diamati ditambah istilah kesalahan yang tidak dapat diobservasi ( $\varepsilon$ ) (Verbeek, 2004).

$$
\begin{aligned}
& y_{i}^{*}=\beta_{i} x_{i}+\varepsilon_{i} \quad \varepsilon_{i} \sim \text { Logistik }(0,1) \\
& \text { dengan } y_{i}=\left\{\begin{array}{l}
1 \text { jika } y_{i}^{*}>0 \\
0 \text { jika } y_{i}^{*}<0
\end{array}\right.
\end{aligned}
$$

Adapun model logit yang akan diestimasi adalah sebagai berikut

$$
\begin{aligned}
& \text { Ln }\left(\frac{\mathrm{y}_{1}}{y_{0}}\right)=\alpha+\beta_{1} \text { Share }_{\text {self }}+ \\
& \beta_{2} \text { Share }_{\text {cash }}+\beta_{3} \text { UMUR }+\beta_{4} J K+ \\
& \beta_{5} \text { PEND }+\beta_{6} M I L I K S E N D I R I+ \\
& \beta_{7} M U S I M+\beta_{8} I N F O+\beta_{9} S K A L A+ \\
& \beta_{10} H A M A+\beta_{11} \text { BANT_PEMERINTAH }+ \\
& \beta_{12} \text { BANT_NONPEMERINTAH }+\varepsilon \ldots . . .(2)
\end{aligned}
$$


Variabel yang diduga mempengaruhi keputusan petani tanaman pangan di Indonesia dalam melakukan diversifikasi adalah nilai produksi yang dikonsumsi sendiri, nilai produksi hasil penjualan, umur petani utama, jenis kelamin petani utama,

Tabel 1

Definisi Operasional Variabel pendidikan petani utama, kepemilikan lahan, menerima bantuan pemerintah, menerima bantuan nonpemerintah, musim tanam, serangan hama, akses informasi dan luas lahan yang dikelola.

\begin{tabular}{|c|c|c|}
\hline No & Nama Variabel & Definisi Operasional \\
\hline$(1)$ & $(2)$ & $(3)$ \\
\hline \multicolumn{3}{|c|}{ Variabel Terikat } \\
\hline & DIV & $\begin{array}{c}\text { Menunjukkan keputusan petani untuk mempraktikkan } \\
\text { diversifikasi terhadap usaha pertanian tanaman } \\
\text { pangannya }\end{array}$ \\
\hline \multicolumn{3}{|c|}{ Variabel Bebas } \\
\hline 1 & Share_self & $\begin{array}{l}\text { Variabel kontinyu yang menggambarkan nilai tanaman } \\
\text { pangan yang dikonsumsi sendiri oleh rumah tangga } \\
\text { tani; merupakan imputasi kuantitas tanaman pangan } \\
\text { yang dikonsumsi sendiri dengan harga pembelian. }\end{array}$ \\
\hline 2 & Share_cash & $\begin{array}{l}\text { Variabel kontinyu yang menunjukkan pendapatan tunai } \\
\text { yang diterima dari hasil penjualan produksi tanaman } \\
\text { pangan. }\end{array}$ \\
\hline 3 & $U M U R$ & $\begin{array}{l}\text { Variabel kontinyu yang dihitung dalam satuan tahun. } \\
\text { Dalam SOUT2017, umur didefinisikan sebagai ulang } \\
\text { tahun terakhir. }\end{array}$ \\
\hline \multirow{3}{*}{4} & \multirow{3}{*}{$J K$} & Variabel ini akan bernilai: \\
\hline & & 1 jika petani utama berjenis kelamin laki-laki \\
\hline & & 0 jika petani utama berjenis kelamin perempuan. \\
\hline \multirow{3}{*}{5} & \multirow{3}{*}{$P E N D$} & Variabel ini akan bernilai: \\
\hline & & $\begin{array}{l}1 \text { jika pendidikan yang ditamatkan SMA \& SMA ke } \\
\text { atas (tamat SLTA/sederajat, tamat perguruan tinggi) }\end{array}$ \\
\hline & & $\begin{array}{l}0 \text { jika pendidikan yang ditamatkan SMA ke bawah } \\
\text { (tidak tamat SD/sederajat, tamat SD/sederajat, tamat } \\
\text { SLTP/sederajat) }\end{array}$ \\
\hline \multirow{4}{*}{6} & \multirow{4}{*}{ MILIKSENDIRI } & $\begin{array}{l}\text { Menunjukkan status kepemilikan bidang lahan yang } \\
\text { menjadi unit observasi. }\end{array}$ \\
\hline & & Variabel ini akan bernilai: \\
\hline & & 1 jika status kepemilikan lahan berupa milik sendiri \\
\hline & & $\begin{array}{l}0 \text { jika status kepemilikan lahan bukan milik sendiri } \\
\text { melainkan sewa, bagi hasil, ataupun lainnya. }\end{array}$ \\
\hline \multirow{2}{*}{7} & \multirow{2}{*}{ MUSIM } & Variabel ini akan bernilai: \\
\hline & & 1 jika kegiatan penanaman dilakukan pada musim hujan \\
\hline
\end{tabular}




\begin{tabular}{|c|c|c|}
\hline No & Nama Variabel & Definisi Operasional \\
\hline \multirow[t]{3}{*}{ (1) } & $(2)$ & (3) \\
\hline & & $\begin{array}{l}0 \text { jika kegiatan penanaman dilakukan pada musim } \\
\text { kemarau. }\end{array}$ \\
\hline & & $\begin{array}{l}\text { Menunjukkan banyaknya sumber informasi yang dapat } \\
\text { diakses rumah tangga. Sumber informasi berasal dari } \\
\text { kegiatan penyuluhan/bimbingan pertanian dan } \\
\text { kelompok tani. }\end{array}$ \\
\hline \multirow[t]{2}{*}{8} & INFO1 & Variabel ini akan bernilai: \\
\hline & & $\begin{array}{l}1 \text { jika rumah tangga pernah mengikuti penyuluhan dan } \\
\text { atau bergabung dengan kelompok tani }\end{array}$ \\
\hline & & $\begin{array}{l}0 \text { jika rumah tangga tidak pernah mengikuti penyuluhan } \\
\text { dan tidak bergabung dalam kelompok tani. }\end{array}$ \\
\hline \multirow[b]{2}{*}{9} & & Variabel ini akan bernilai: \\
\hline & $S K A L A$ & $\begin{array}{l}1 \text { jika petani mengelola lahan seluas } 1 \text { hektar atau lebih } \\
0 \text { jika petani mengelola lahan seluas kurang dari } 1 \\
\text { hektar }\end{array}$ \\
\hline \multirow{3}{*}{10} & & Variabel ini akan bernilai: \\
\hline & $H A M A$ & 1 jika petani mengalami serangan hama \\
\hline & & 0 jika tidak mengalami serangan hama \\
\hline \multirow{3}{*}{11} & & Variabel ini akan bernlai: \\
\hline & BANT_PEMERINTAH & $\begin{array}{l}1 \text { jika petani mendapat bantuan pertanian yang } \\
\text { bersumber dari pemerintah }\end{array}$ \\
\hline & & $\begin{array}{l}0 \text { jika tidak mendapat bantuan pertanian yang } \\
\text { bersumber dari pemerintah }\end{array}$ \\
\hline \multirow[t]{2}{*}{12} & BANT_NONPEMERINTAH & $\begin{array}{l}\text { Variabel ini akan bernlai: } \\
1 \text { jika petani mendapat bantuan pertanian yang } \\
\text { bersumber dari lembaga nonpemerintah }\end{array}$ \\
\hline & & $\begin{array}{l}0 \text { jika tidak mendapat bantuan pertanian yang } \\
\text { bersumber dari lembaga nonpemerintah }\end{array}$ \\
\hline
\end{tabular}

Sumber: SOUT2017, diolah

\section{HASIL DAN PEMBAHASAN}

\section{Deskriptif Petani Tanaman Pangan}

Dalam penelitian ini, hanya digunakan petani utama yang berumur 15 tahun ke atas. Penetapan tersebut didasarkan pada penelitian Sutter et al (2019) dan Barash et al (2018) dalam (Pratiwi, 2020) yang menyebutkan bahwa petani utama yang berumur kurang dari 15 tahun dianggap belum memiliki rasionalitas yang baik sehingga belum memiliki kemampuan yang baik pula dalam mengambil keputusan. Oleh karena itu, usia petani utama di penelitian menggunakan batas usia 15 tahun ke atas. Rata-rata umur petani utama yang mengelola pertanian tanaman pangan di Indonesia adalah 51 tahun. Petani muda yang berusia kurang dari 51 tahun lebih memilih diversifikasi yaitu sebanyak 61,4 persen, sedangkan petani yang berusia 51 atau lebih 
akan cenderung melakukan spesialisasi terhadap tanamannya. Petani Padi Palawija di Indonesia masih didominasi oleh laki-laki dan lebih dari separuhnya menerapkan praktik diversifikasi. Selanjutnya, petani dengan tingkat pendidikan SMA ke bawah yang melakukan diversifikasi sebanyak 61,9 persen sedangkan petani dengan pendidikan lebih tinggi yang memilih diversifikasi hanya 56,9 persen. Tanpa mengontrol variabel lainnya, hasil ini mengindikasikan bahwa semakin tinggi pendidikan, petani akan menerima lebih banyak ilmu sehingga mampu mempertimbangkan dan memutuskan teknik yang lebih menguntungkan.

Sebelum dikontrol variabel lain, karakteristik demografi petani yang cenderung melakukan diversifikasi adalah petani utama yang berjenis kelamin perempuan, berusia kurang dari sama dengan 50 tahun, berpendidikan tinggi. Karakteristik lainnya yang secara deskriptif kecenderungannya melakukan diversifikasi yaitu nilai produksinya lebih kecil, memiliki lahan sendiri, menanam di musim kemarau, tidak mendapat akses informasi, mengelola lahan kurang dari 1 hektar, tidak mengalami serangan hama, tidak mendapat bantuan pemerintah maupun non pemerintah.

\section{Karakteristik Ekonomi}

Sebagian petani di negara berkembang bertindak sebagai konsumen sekaligus produsen sehingga profitabilitas pertanian menjadi ambigu (Dillon \& Barrett, 2017). Di Indonesia, rata-rata nilai produksi pertanian tanaman pangan yang dikonsumsi sendiri adalah Rp 594.000,00 sedangkan pendapatan tunai yang diperoleh dari penjualan hasil produksi senilai Rp 235.000,00. Petani dengan nilai produksi yang dikonsumsi di atas rata-rata lebih memilih spesialisasi dari pada diversifikasi.
Sebanyak 50,6 persen petani dengan nilai produksi yang dikonsumsi di atas rata-rata akan memilih diversifikasi sedangkan pada petani yang mengonsumsi hasil produksi di bawah rata-rata dan memilih diversifikasi sebanyak 68,2 persen. Begitu pula dengan petani yang nilai menjual hasil produksinya di bawah rata-rata akan cenderung untuk diversifikasi sebanyak 57,7 persen sedangkan yang di atas rata-rata lebih besar yakni 65,1 persen. Pada petani dengan nilai menjual hasil produksi yang rendah, mereka mengalami kesulitan memprediksi volume produksi pertanian apa saja yang akan dihasilkan (Budhi, 2010). Hal ini menjadikan pilihan memproduksi satu jenis tanaman akan lebih berisiko bagi petani, dibandingkan dengan memproduksi lebih dari satu jenis tanaman.

\section{Kepemilikan Tanah dan Luas Lahan yang Dikelola}

Secara deskriptif, petani tanaman pangan yang memiliki lahan sendiri akan menerapkan diversifikasi (FAO, 2010). Sebanyak 61,3 persen petani yang memiliki lahan sendiri melakukan diversifikasi terhadap tanaman pangannya. Sedangkan petani yang tidak memiliki lahan sendiri dan melakukan diversifikasi hanya 60,6 persen. Adapun petani yang mengelola lahan lebih dari sama dengan 1 hektar dan melakukan diversifikasi sebanyak 55,4 persen. Petani dengan lahan yang dikelola kurang dari 1 hektar dan melakukan diversifikasi sebanyak 63,5 persen. Petani akan berusaha meningkatkan nilai produksi dengan diversifikasi meskipun dengan lahan yang terbatas.

\section{Kondisi Cuaca}

Kondisi cuaca khususnya curah hujan memainkan peran yang sangat penting dalam tingkat produksi tanaman dan produktivitas tanaman pokok (Mukuka \& 
Hichaambwa, 2018). Dari seluruh petani yang menanam di musim hujan, 57,7 persennya melakukan diversifikasi sedangkan sisanya memilih menanam satu tanaman saja. Kecenderungan ini didukung oleh penelitian sebelumnya (Bellon, Kotu, Azzarri, \& Caracciolo, 2020; Kawa, Clavijo Michelangeli, \& Clement, 2015) bahwa produksi tanaman pangan bergantung pada kecukupan air. Oleh karena itu, musim hujan dimanfaatkan petani untuk menanam berbagai tanaman pangan untuk menghasilkan volume produksi yang optimal. Sedangkan pada musim kemarau, 72,8 persen petani memilih diversifikasi selebihnya melakukan spesialisasi. (Asfaw, Scognamillo, Caprera, Sitko, \& Ignaciuk, 2019) menjelaskan bahwa kondisi kekeringan mendorong petani untuk melakukan diversifikasi. Hal ini dilakukan karena kekeringan membuat produksi tanaman pangan mereka menurun, sehingga upaya yang dilakukan dengan mencoba (risk aversion) melakukan penanaman pada jenis tanaman lainnya.

\section{Akses Informasi}

Berdasarkan deskriptif data ini, ada 56,0 persen petani yang mendapatkan penyuluhan pertanian dan atau bergabung dalam kelompok tani serta melakukan praktik diversifikasi. Petani yang tidak mendapat akses informasi melalui penyuluhan maupun menjadi anggota kelompok tani yang melakukan diversifikasi sebanyak 67,4 persen. Kecenderungan melakukan diversifikasi pada petani yang mendapatkan penyuluhan pertanian atau menjadi anggota kelompok tani, lebih rendah daripada petani yang tidak menerima penyuluhan atau menjadi anggota kelompok tani. Akses informasi yang diperoleh memungkinkan petani untuk melakukan strategi peningkatan produksi cukup dengan satu jenis tanaman. Petani yang sudah mampu mengatasi keterbatasan sistem monokultur melalui penyuluhan atau bimbingan kelompok tani kecil kemungkinan untuk melakukan diversifikasi. Pendapat ini perlu diuji kembali dengan melibatkan variabel kontrol lainnya.

\section{Serangan Hama}

Sebanyak 50,5 persen petani pertanian pangan yang mengalami serangan hama melakukan diversifikasi selebihnya memilih melakukan spesialisasi. Petani yang tidak mengalami serangan hama dan melakukan diversifikasi sebanyak 78,4 persen. Kecenderungan melakukan diversifikasi pada petani yang terdampak serangan hama lebih tinggi dari yang tidak. Hal ini mengindikasikan bahwa petani akan berupaya semaksimal mungkin untuk menutupi kerugian akibat serangan hama dengan menanam jenis tanaman lainnya. Tentu saja hal ini perlu diuji secara inferensia.

\section{Kelembagaan}

Penulis menggunakan pendekatan variabel bantuan dari pemerintah dan nonpemerintah untuk melihat keterlibatan kelembagaan dalam keputusan diversifikasi pertanian tanaman pangan. Pada tahun 2017 petani yang mendapat bantuan pemerintah dan melakukan diversifikasi sebanyak 52,8 dan yang tidak mendapat bantuan dari pemerintah namun melakukan diversifikasi sebanyak 67,7 persen. Sejalan dengan sebelumnya, petani yang tidak mendapat bantuan dari non pemerintah dan melakukan diversifikasi sebanyak 61,1 persen. Sedangkan petani yang mendapat bantuan dan melakukan diversifikasi sebanyak 58,3 persen. 
Tabel 2.

Persentase Rumah Tangga Pertanian Tanaman Pangan Menurut Karakteristik Rumah Tangga dan Keputusan Diversifikasi di Indonesia Tahun 2017

\begin{tabular}{|c|c|c|c|}
\hline \multicolumn{2}{|c|}{ Karakteristik Rumah Tangga } & Spesialisasi & Diversifikasi \\
\hline \multicolumn{2}{|c|}{$(1)$} & $(2)$ & (3) \\
\hline \multirow{2}{*}{ Jenis Kelamin } & Laki-Laki & 39,3 & 60,7 \\
\hline & Perempuan & 35,1 & 64,9 \\
\hline \multirow{2}{*}{ Umur } & $>50$ tahun & 39,2 & 60,8 \\
\hline & $\leq 50$ tahun & 38,6 & 61,4 \\
\hline \multirow{2}{*}{ Pendidikan } & Tamat SMA Dan Perguruan Tinggi & 43,1 & 56,9 \\
\hline & Tamat SMA Ke Bawah & 38,1 & 61,9 \\
\hline \multirow{2}{*}{$\begin{array}{l}\text { Nilai Produksi Yang } \\
\text { Dikonsumsi Sendiri }\end{array}$} & $>594.000$ & 49,4 & 50,6 \\
\hline & $\leq 594.000$ & 31,8 & 68,2 \\
\hline \multirow{2}{*}{$\begin{array}{l}\text { Nilai Produksi Yang } \\
\text { Dijual }\end{array}$} & $>235.000$ & 42,3 & 57,7 \\
\hline & $\leq 235.000$ & 34,9 & 65,1 \\
\hline \multirow{2}{*}{ Kepemilikan Tanah } & Milik Sendiri & 38,7 & 61,3 \\
\hline & Sewa/Bebas Sewa/Lainnya & 39,4 & 60,6 \\
\hline \multirow{2}{*}{ Musim Tanam } & Hujan & 42,3 & 57,7 \\
\hline & Kemarau & 27,2 & 72,8 \\
\hline \multirow{2}{*}{ Akses Informasi } & $\begin{array}{c}\text { Mendapat Penyuluhan Pertanian } \\
\text { Dan Atau Menjadi Anggota } \\
\text { Kelompok Tani }\end{array}$ & 44,0 & 56,0 \\
\hline & $\begin{array}{c}\text { Tidak Mengikuti Penyuluhan Dan } \\
\text { Atau Menjadi Anggota Kelompok } \\
\text { Tani }\end{array}$ & 32,6 & 67,4 \\
\hline \multirow{2}{*}{ Skala Petani } & $\begin{array}{l}\text { Mengelola Lahan Seluas } 1 \text { Hektar } \\
\text { Atau Lebih }\end{array}$ & 44,6 & 55,4 \\
\hline & $\begin{array}{c}\text { Mengelola Lahan Seluas Kurang } \\
\text { Dari } 1 \text { Hektar }\end{array}$ & 36,5 & 63,5 \\
\hline \multirow{2}{*}{ Serangan Hama } & Mengalami Serangan Hama & 49,5 & 50,5 \\
\hline & Tidak Mengalami Serangan Hama & 21,6 & 78,4 \\
\hline \multirow{2}{*}{ Bantuan Pemerintah } & $\begin{array}{l}\text { Mendapat Bantuan Yang } \\
\text { Bersumber Dari Pemerintah }\end{array}$ & 47,2 & 52,8 \\
\hline & $\begin{array}{c}\text { Tidak Mendapat Bantuan Yang } \\
\text { Bersumber Dari Pemerintah }\end{array}$ & 32,3 & 67,7 \\
\hline \multirow{2}{*}{$\begin{array}{c}\text { Bantuan Non } \\
\text { Pemerintah }\end{array}$} & $\begin{array}{l}\text { Mendapat Bantuan Yang } \\
\text { Bersumber Dari Nonpemerintah }\end{array}$ & 41,7 & 58,3 \\
\hline & $\begin{array}{l}\text { Tidak Mendapat Bantuan Yang } \\
\text { Bersumber Dari Nonpemerintah }\end{array}$ & 38,9 & 61,1 \\
\hline
\end{tabular}

Sumber: SOUT2017, diolah

Berdasarkan uji signifikansi model Uji Likelihood Ratio dimana hipotesisnya menggunakan Omnibus Tests of Model sebagai berikut:

Coefficients, kita dapat melihat hasil $H_{0}: \beta_{1}=\beta_{2}=\cdots=\beta_{12}=\beta_{p}=0 \quad$ (tidak pengujian secara simultan pengaruh variabel ada pengaruh variabel bebas secara bebas terhadap keputusan petani melakukan simultan terhadap variabel terikat) diversifikasi. Pengujian ini menggunakan 
$H_{1}$ : minimal ada satu $\beta_{p} \neq 0$ (ada pengaruh paling sedikit satu variabel bebas terhadap variabel terikat)

Adapun statistik ujinya mengikuti distribusi Chi-Square dengan derajat bebas sejumlah 12. Pada tingkat kepercayaan 95 persen kita menolak Ho sehingga disimpulkan bahwa variabel bebas yang digunakan, secara bersama-sama mempengaruhi keputusan diversifikasi. Hasil ini menunjukkan bahwa minimal ada satu variabel bebas yang berpengaruh pada peluang petani melakukan diversifikasi.

Tabel 3.

Omnibus Tests of Model Coefficients

\begin{tabular}{lllll}
\hline & & Chi-square & df & \multicolumn{1}{l}{ Sig. } \\
\hline \multirow{3}{*}{ Step 1 } & Step & 91758,449 & 12 &, 000 \\
\cline { 2 - 5 } & Block & 91758,449 & 12 &, 000 \\
\cline { 2 - 5 } & Model & 91758,449 & 12 &, 000 \\
\hline
\end{tabular}

Persentase ketepatan model dalam pengklasifikasiannya oleh model regresi mengklasifikasikan observasi adalah 80,8 logistik. Jumlah observasi yang tepat persen. Artinya dari 356.000 observasi, ada pengklasifikasiannya dapat dilihat pada 287.648 observasi yang tepat diagonal utama.

Tabel 4.

Klasifikasi Model

\begin{tabular}{lllllr}
\hline & & \multicolumn{3}{c}{ Predicted } \\
\cline { 3 - 5 } & & \multicolumn{2}{c}{$\begin{array}{c}\text { Keputusan } \\
\text { Obsersifikasi }\end{array}$} & \multirow{2}{*}{$\begin{array}{c}\text { Percentage } \\
\text { Correct }\end{array}$} \\
\cline { 3 - 4 } & & 0 & 1 & \\
\hline \multirow{2}{*}{ Step 1 } & Keputusan & 0 & 74044 & 22634 & 76,6 \\
\cline { 3 - 5 } & Diversifikasi & 1 & 15655 & 87176 & 84,8 \\
\cline { 2 - 5 } & Overall Percentage & & & & 80,8 \\
\hline
\end{tabular}

The cut value is ,500

Sumber: SOUT2017, diolah

Pada pengujian parsial menggunakan uji Wald dan diharapkan Ho akan ditolak sehingga variabel yang sedang diuji masuk ke dalam model. Dengan bantuan tabel berikut dapat dilihat variabel mana saja yang berpengaruh signifikan sehingga bisa dimasukkan ke model. Jika nilai p-value < 0,05 maka Ho ditolak. Model regresi logistik menunjukkan bahwa variabel bebas yang signifikan pada level 5 persen yaitu nilai produksi yang dikonsumsi sendiri, nilai produksi hasil penjualan, umur petani utama, pendidikan petani utama, kepemilikan lahan, menerima bantuan pemerintah, menerima bantuan nonpemerintah, musim tanam, serangan hama, akses informasi dan luas lahan yang dikelola. 
Tabel 5.

Pengujian Parsial dan Hasil Estimasi Regresi Logistik

\begin{tabular}{|c|c|c|c|c|c|}
\hline Variabel & B & S.E. & Wald & df & $\operatorname{Exp}(B)$ \\
\hline (1) & (2) & (3) & $(4)$ & (5) & $(6)$ \\
\hline Share_self &,$- 002 *$ & 000 & 526,205 & 1 & ,998 \\
\hline Share_cash &,$- 077 *$ & ,000 & 30149,942 & 1 & ,925 \\
\hline UMUR &,$- 011 *$ & ,000 & 471,456 & 1 & ,989 \\
\hline $\mathrm{JK}(1)$ &,- 027 & ,020 & 1,880 & 1 & ,973 \\
\hline $\operatorname{PEND}(1)$ & ,338* & ,016 & 428,999 & 1 & 1,402 \\
\hline MILIKSENDIRI(1) &,$- 386^{*}$ & ,013 & 903,081 & 1 & ,680 \\
\hline BANT_PEMERINTAH(1) & ,948* & 012 & 5981,791 & 1 & 2,580 \\
\hline BANT_NONPEMERINTAH(1) &, $649 *$ & ,090 & 52,457 & 1 & 1,913 \\
\hline MUSIM(1) &, $673 *$ &, 015 & 2064,820 & 1 & 1,959 \\
\hline HAMA(1) & $1,049 *$ & ,013 & 7027,959 & 1 & 2,855 \\
\hline INFO1(1) &, $489 *$ &, 012 & 1571,563 & 1 & 1,631 \\
\hline SKALA(1) &,$- 337 *$ &, 015 & 528,564 & 1 &, 714 \\
\hline Constant &, $144 *$ & ,095 & 2,274 & 1 & 1,154 \\
\hline
\end{tabular}

Sumber: SOUT2017, diolah

Setelah dikontrol variabel lain, berikut hasil inferensia dari penelitian ini menggunakan analisis odds ratio. Secara umum, peluang petani melakukan diversifikasi lebih besar daripada spesialisasi dalam pertanian tanaman pangan apabila nilai produksi baik yang dikonsumsi maupun yang dijual lebih kecil serta berlaku pada petani berpendidikan tinggi. Selain itu, karakteristik yang secara inferensia menjadi alasan melakukan diversifikasi adalah jika petani mengelola lahan yang disewa atau lainnya, luas lahan yang dikelola kurang dari 1 hektar, mendapatkan bantuan dari pemerintah dan atau dari non pemerintah, menanam di musim hujan, terkena serangan hama dan mendapatkan akses informasi.

Berdasarkan odds ratio pada tabel 6.3 kolom 6, maka diperoleh hasil sebagai berikut. Faktor demografis petani mempengaruhi keputusan teknik diversifikasi terhadap tanaman pangannya. Semakin bertambah umur petani cenderung
0,989 kali lebih rendah untuk melakukan diversifikasi pertanian. Selain itu petani dengan tingkat pendidikan SMA dan lebih, akan berpeluang 1,402 kali lebih besar untuk mempraktikkan diversifikasi pertanian.

Berdasarkan share nilai produksi yang dikonsumsi sendiri, semakin besar nilai produksi yang dikonsumsi sendiri oleh rumah tangga petani maka petani tersebut 0,998 kali lebih rendah untuk melakukan diversifikasi. Sejalan dengan itu, semakin besar nilai tunai hasil penjualan tanaman pangannya maka peluang untuk melakukan diversifikasi 0,925 kali lebih rendah. Hal ini diduga karena keputusan diversifikasi pertanian merupakan solusi bagi petani saat nilai produksi pertaniannya rendah.

Peluang diversifikasi tanaman pangan yang lebih tinggi pada petani subsisten yang nilai produksinya di bawah rata-rata mengindikasikan bahwa petani akan melakukan berbagai pilihan demi memenuhi kebutuhan pangan rumah tangganya. 
Sebagai tambahan, ketika peluang pasar untuk menjual hasil produksinya itu tinggi, petani akan melakukan diversifikasi untuk meningkatkan ekonomi rumah tangganya. Hal ini sesuai dengan penelitian (Bellon, Kotu, Azzarri, \& Caracciolo, 2020).

Kepemilikan lahan pertanian turut berkontribusi dalam penentuan diversifikasi pertanian. Petani dengan lahan milik sendiri berpeluang 0,680 lebih rendah untuk melakukan diversifikasi daripada fokus pada satu jenis tanaman. Adapun petani yang mengelola lahan pertanian lebih dari 1 hektar memiliki kecenderungan 0,714 kali lebih rendah untuk mempraktikkan diversifikasi.

Variabel lain yang mempengaruhi keputusan diversifikasi pertanian adalah musim tanam dan serangan hama. Petani yang menanam pada musim hujan cenderung 1,959 kali untuk menanam lebih dari satu jenis tanaman. Di faktor lain, jika terkena serangan hama, petani akan cenderung 2,855 kali untuk memvariasikan tanamannya daripada hanya menanam satu jenis tanaman. Pengetahuan petani juga signifikan mempengaruhi keputusan diversifikasi. Petani yang mendapatkan informasi melalui penyuluhan dan atau menjadi anggota kelompok tani berpeluang 1,631 kali lebih tinggi untuk melakukan diversifikasi. Sebagai karakteristik kelembagaan, petani yang mendapat bantuan dari pemerintah akan memiliki kecenderungan untuk melakukan diversifikasi sebesar 2,580 kali lebih besar daripada melakukan spesialisasi pertanian.
Demikian pula pada petani yang mendapat bantuan dari pihak swasta atau selain pemerintah, ia akan berpeluang 1,913 kali lebih besar untuk mempraktikkan diversifikasi terhadap tanamannya.

\section{SIMPULAN}

Berdasarkan hasil analisis, dapat diperoleh kesimpulan sebagai berikut. Petani memutuskan untuk melakukan diversifikasi saat kondisi terbatas dari sisi pendapatan dan kepemilikan lahan bukan milik sendiri serta kondisi tanaman yang buruk akibat serangan hama. Jika petani sudah mendapatkan kondisi yang stabil misal usia semakin matang, nilai produksi yang sudah meningkat dan sudah memiliki lahan pertanian milik sendiri maka mereka dapat fokus untuk menanam satu jenis tanaman.

Berdasarkan kesimpulan di atas, penulis merekomendasikan pemerintah untuk fokus memberikan bantuan kepada petani yang melakukan diversifikasi. Penelitian selanjutnya perlu dilakukan untuk menganalisis seperti apa bentuk bantuan usaha pertanian yang mendukung diversifikasi dan bagaimana mekanisme distribusinya sehingga bisa dirasakan efektivitasnya dalam meningkatkan produksi. Dengan adanya asosiasi negatif antara diversifikasi dengan kepemilikan lahan, pemerintah dengan dapat memberikan insentif dengan meringankan biaya sewa lahan sehingga petani kecil mampu melakukan diversifikasi.

\section{DAFTAR PUSTAKA}

Alkire, S., Kanagaratnam, U., \& Suppa, N. (2015). The Global Multidimensional Poverty Index (MPI) 2019. University of Oxford, Oxford Department of International Development. OPHI MPI METHODOLOGICAL NOTE 47. 
Bellon, M. R., Gotor, E., \& Caracciolo, F. (2015). Conserving landraces and improving livelihoods: how to assess the success of on farm. International Journal of Agricultural Sustainability, 13(2), 167-182.

Bellon, M. R., Kotu, B. H., Azzarri, C., \& Caracciolo, F. (2020, Januari). To diversify or not to diversify, that is the question. Pursuing agricultural development for smallholder farmers in marginal areas of Ghana. World Development, 125.

BPS. (2018). Hasil Survei Pertanian Antar Sensus (SUTAS2018). Jakarta: Badan Pusat Statistik.

Dillon, B., \& Barrett, C. B. (2017). Agricultural factor markets in Sub-Saharan Africa: An updated view with formal tests for market failure. Food Policy, 64-77.

Emran, M. S., \& Shilpi, F. (2012). The Extent of the Market and Stages of Agricultural Specialization. Policy Research Working Paper.

Mattila, P., \& Wiro. (1999). Economic Theories Of The Household A Critical Review. Working Paper No. 159.

Mu'min, A., Hastuti, K. P., \& Angriani, P. (2014). Pengaruh Diversifikasi Pertanian Terhadap Pendapatan masyarakat di Desa Belawang Kecamatan Belawang Kabupaten Barito Kuala. Jurnal Pendidikan Geografi, 8-20.

Mukuka, R. M., \& Hichaambwa, M. (2018). Livelihood effects of crop diversification: a panel data analysis of rural farm households in Zambia. Food Security, 1449-1462.

Pope, R. D., \& Prescott, R. (1980). Diversification in Relation to Farm Size and Other Socioeconomic Characteristics. American Journal of Agricultural Economics, 554559.

Pratiwi, A. (2020). Sustainable Farming : Respon Petani Tanaman Pangan Terhadap Kepemilikan Lahan Pertanian. Depok: Universitas Indonesia.

Singh, I., Squire, L., \& Strauss, J. (1986). A Survey of Agricultural Household Models: Recent Findings and Policy Implications. The World Bank Economic Review, 149-179.

Timmer, C. P. (1997, May). Farmers and Markets: The Political Economy of New Paradigms. American Journal of Agricultural Economics, 79(2), 621.

United Nations. (2015). Sustainable Development Goals. Retrieved April 16, 2020, from https://sustainabledevelopment.un.org/?menu=1300

Verbeek, M. (2004). A Guide to Modern Econometrics. Chichester: John Wiley \& Sons Ltd. 